\title{
Molecular analysis of Shigella sonnei isolated from three well-documented outbreaks in school children
}

\author{
TSONG-MING LEE, LIN-LI CHANG*, CHUNG-YU CHANG*, JINN-CHYI WANG, TZU-MING PAN†, \\ TIEN-KUEI WANG $\dagger$ and SHUI-FENG CHANG* \\ Department of Food Sanitation, Tajen Junior College of Pharmacy, Ping Tung 907, * Department of \\ Microbiology, Kaohsiung Medical College, Kaohsiung 807 and $\uparrow$ National Institute of Preventive Medicine, \\ Department of Health, Taipei 115, Taiwan, ROC
}

\begin{abstract}
Fifty-eight isolates of Shigella sonnei from three outbreaks in school children and eight control isolates from epidemiologically unrelated sporadic clinical infections in Taiwan were compared by antibiotic susceptibility testing and molecular typing. Antibiotic susceptibility testing showed that all strains except one sporadic isolate were multiresistant. Ribotyping after restriction endonuclease digestion with SalI, Pvu II and HindII generated the same ribosomal pattern in 65 of the 66 isolates. Plasmid profile analysis and pulsed-field gel electrophoresis (PFGE) produced eight and nine distinct patterns, respectively, and were in agreement with the epidemiological relationship of the outbreak strains. Nevertheless, some of the sporadic isolates could be discriminated only by a combination of these two methods. This study showed that plasmid profiling in combination with PFGE may be superior to ribotyping in molecular epidemiological investigations of $S$. sonnei.
\end{abstract}

\section{Introduction}

Infection caused by Shigella spp. remains a serious public health problem in both developing and developed countries and is the major cause of diarrhoeal disease in Taiwan $[1,2]$. Outbreaks of infection due to Shigella spp. are difficult to control because of their low infective dose [3], the ease of spread by person-toperson transmission by the faecal-oral route [4] and their ability to spread indirectly by faecal contamination of food and water [5]. In recent years, S. flexneri and $S$. sonnei have been the most prevalent species causing shigellosis in Taiwan [1], but few epidemiological studies have been reported. In epidemiology, tracing the source of an infection is an important step in the control of transmission and the identification of the epidemic strain in the course of an outbreak investigation is the prerequisite for the discrimination of the causative clone and its reservoir.

In the past, several conventional typing methods including biotyping, colicin typing, bacteriophage typing and drug resistance pattern have been used in

Received 1 April 1999; revised version accepted 13 Sept. 1999.

Corresponding author: Dr S.-F. Chang (e-mail: shui@mail. nsysu.edu.tw). epidemiological subtyping of $S$. sonnei $[2,6,7]$, but the usefulness of these techniques is limited by problems common to typing systems based on phenotypic properties [8]. Recently, approaches at the DNA level have been used to discriminate between bacterial isolates. Plasmid profile analysis $[9,10]$, ribotyping $[11,12]$ and pulsed-field gel electrophoresis (PFGE) $[13,14]$ have proved to be useful in discriminating isolates of Shigella spp.

The present study was designed to determine the usefulness of these typing methods (plasmid profile analysis, ribotyping and PFGE) for differentiating strains of $S$. sonnei obtained from three well-documented outbreaks in three different counties of Taiwan during the period 1993-1997 and to investigate the clonal relationships between them. At the same time, eight epidemiologically unrelated isolates of $S$. sonnei obtained from sporadic clinical sources between 1985 and 1987 were studied for comparison.

\section{Materials and methods}

Diarrhoeal outbreaks

Three common-source epidemics (waterborne) of $S$. sonnei shigellosis occurred in three primary schools during the period Sept. 1993-Oct. 1997. The first 
outbreak (outbreak 1) occurred in Taichung City, Taiwan, in September 1993. One hundred stool specimens from 739 children with diarrhoea were cultured and isolates were confirmed as S. sonnei. The second outbreak (outbreak 2) occurred in Taoyuan County, Taiwan, in November 1995. In this outbreak, 404 isolates from stool specimens from 715 children with diarrhoea were confirmed as $S$. sonnei. The third outbreak (outbreak 3) of diarrhoea was in Hsinchu County, Taiwan, in October 1997. Stool specimens from 442 school children were cultured, with 123 isolates confirmed as $S$. sonnei; 76 of these children had diarrhoeal symptoms and 47 were symptom-free.

\section{Bacterial strains}

A total of 66 randomly selected isolates of $S$. sonnei were analysed in the study (Table 1). These included 25 isolates from outbreak 1, 20 isolates from outbreak 2, 13 from outbreak 3, and 8 isolates from epidemiologically unrelated sporadic clinical infections that occurred between 1985 and 1987. A type strain of $S$. sonnei (ATCC 9290) was included for comparison. All the isolates were characterised by biochemical and serological tests. Subsequently, all strains were stored at $-70^{\circ} \mathrm{C}$ in Tryptic Soy Broth (Difco, Detroit, MI, USA) containing glycerol $15 \%$ until processing.

\section{Antibiotic susceptibility testing}

Isolates were tested for susceptibility to ampicillin (AM, $10 \mu \mathrm{g}$ ), piperacillin (PIP, $100 \mu \mathrm{g}$ ), cefotaxime (CTX, $30 \mu \mathrm{g}$ ), ceftizoxime (ZOX, $30 \mu \mathrm{g})$, imipenem (IPM, $10 \mu \mathrm{g}$ ), amikacin (AN, $30 \mu \mathrm{g}$ ), gentamicin (GM, $10 \mu \mathrm{g}$ ), netilmicin (NET, $30 \mu \mathrm{g}$ ), tetracycline (TE, $30 \mu \mathrm{g}$ ), nalidixic acid (NA, $30 \mu \mathrm{g}$ ), chloramphenicol (C, $30 \mu \mathrm{g}$ ) and trimethoprim/sulphamethoxazole (SXT, $25 \mu \mathrm{g})$ by the Kirby-Bauer disk diffusion method [15] and the resistance breakpoints used were those recommended by the National Committee for Clinical Laboratory Standards [16].

\section{Plasmid profile analysis}

Plasmid DNA was extracted by the method of Kado and Liu [17]. Plasmid sizes were calculated by the method of Rochelle et al. [18], with plasmids obtained from Escherichia coli 39R861 (NCTC 50192) as a reference standard. Only small plasmids, which appeared as bright bands below the band of chromosomal DNA on the gel, were included in the analysis. Large plasmids above $20 \mathrm{~kb}$ were not investigated because of their instability [10].

\section{Ribotyping}

Whole-cell DNA was prepared as described by Nastasi et al. [19]. DNA was digested with restriction enzymes HindII, SalI and Pvu II (Boehringer Mannheim GmbH, Mannheim, Germany). DNA fragments were separated by electrophoresis at $100 \mathrm{~V}$ for $4 \mathrm{~h}$, transferred to a nylon membrane, and fixed by spectrolinker (Spectroline, XL-1000/Spectronic, Westbury, NY, USA). Hybridisation was performed with a random primed digoxigenin-11-dUTP-labelled cDNA probe obtained by reverse transcription of a commercially available preparation of $E$. coli $16 \mathrm{~S}+23 \mathrm{~S}$ rRNA (Boehringer Mannheim). The digoxigenin-labelled cDNA probe was detected with anti-digoxigenin antibodies labelled with alkaline phosphatase and luminescent substrate Lumigen-PPD as recommended by the manufacturer (Boehringer Mannheim).

\section{$P F G E$}

PFGE was performed as described previously [20]. Briefly, genomic DNA in agarose plugs was digested with endonuclease $X b a$ I (Boehringer Mannheim). DNA fragments were then separated by electrophoresis on Seakem GTG agarose (FMC, No. 50072; FMC BioProducts, USA) $1.2 \%$ gels in $0.5 \times$ Tris-borateEDTA buffer with Pharmacia-LKB 2015 equipment. The running conditions were $200 \mathrm{~V}$ at $14^{\circ} \mathrm{C}$ for $24 \mathrm{~h}$. The pulse time was increased from 5 to $35 \mathrm{~s}$. Multimeric phage $\lambda(48.5 \mathrm{~kb})$ DNA (Boehringer Mannheim) was used as the molecular size marker. After electrophoresis, the gel was stained with ethidium bromide for $30 \mathrm{~min}$ and de-stained in distilled water for $2 \mathrm{~h}$. DNA bands were then visualised under UV light and photographed.

\section{Results}

\section{Antibiotic susceptibility testing}

According to the antibiotic susceptibility tests (Table 1), all 25 isolates from outbreak 1 were resistant to tetracycline, co-trimoxazole, piperacillin, chloramphenicol and ampicillin, while the strains isolated from outbreaks 2 and 3 were resistant to tetracycline and cotrimoxazole only. Resistance to tetracycline, chloramphenicol and nalidixic acid was found most frequently among the sporadic isolates.

\section{Plasmid profile analysis}

Plasmid profiles of $S$. sonnei isolates are illustrated in Fig. 1 and summarised in Table 1. As expected, strains from the same outbreak possessed their own identical profiles (Table 1; Fig. 1, lanes 9-15). Among the eight sporadic isolates (S59-S66) six had distinct plasmid profiles (Table 1; Fig. 1, lanes 3-8). Isolates S59 and S60 shared the same profile (e) (Fig. 1, lanes 2 and 3). Likewise isolates S63 and S64 had an indistinguishable profile (g) (Fig. 1, lane 6). When profiles of outbreak strains were compared with the profiles of sporadic isolates, outbreak 1 strains shared the same profile (b) (Table 1) with one of the sporadic isolates (S62) isolated 7 years previously. 
Table 1. Characteristics of $S$. sonnei isolates examined in the present study

\begin{tabular}{|c|c|c|c|c|c|c|c|}
\hline \multirow[b]{2}{*}{ Source and isolate } & \multirow{2}{*}{$\begin{array}{l}\text { Date of isolation } \\
\text { (day/month/yr) }\end{array}$} & \multirow{2}{*}{$\begin{array}{l}\text { Antibiogram } \\
\text { pattern }\end{array}$} & \multirow{2}{*}{$\begin{array}{l}\text { Plasmid } \\
\text { profile }\end{array}$} & \multicolumn{3}{|c|}{ rDNA RFLP pattern with } & \multirow{2}{*}{$\begin{array}{l}\text { PFGE } \\
\text { pattern }\end{array}$} \\
\hline & & & & SalI & $P v u \mathrm{II}$ & HindII & \\
\hline Type strain ATCC 9290 & $\ldots$ & $*$ & $\mathrm{a}$ & s1 & p1 & h1 & $\mathrm{i}$ \\
\hline \multicolumn{8}{|l|}{ Outbreak 1 (Taichung city ${ }^{\dagger}$ ) } \\
\hline $\mathrm{S} 1-\mathrm{S} 7$ & $13 / 9 / 93$ & PIPr $^{r}$ TE $^{r} C^{r} S_{X T}^{r} A^{r}$ & $\mathrm{~b}$ & s1 & p1 & h1 & ii \\
\hline S8-S13 & $15 / 9 / 93$ & PIPr $^{r}$ E $^{r} C^{r} S_{X T}^{r} A^{r}$ & $\mathrm{~b}$ & s1 & p1 & h1 & ii \\
\hline S14-S17 & $24 / 9 / 93$ & PIPr $^{r}$ E $^{r} C^{r} S_{X T}{ }^{r} A^{r}$ & $\mathrm{~b}$ & s1 & p1 & h1 & ii \\
\hline $\mathrm{S} 18-\mathrm{S} 22$ & $2 / 10 / 93$ & PIP $^{r}$ TE $^{r} C^{r} S_{X T}^{r} A^{r}$ & $\mathrm{~b}$ & s1 & p1 & h1 & ii \\
\hline $\mathrm{S} 23-\mathrm{S} 25$ & $6 / 10 / 93$ & PIP $^{r} T^{r} C^{r} S^{r} T^{r} A^{r}$ & $\mathrm{~b}$ & s1 & p1 & h1 & ii \\
\hline \multicolumn{8}{|c|}{ Outbreak 2 (Taoyuan County $\left.{ }^{+}\right)$} \\
\hline S26-S38 & $20 / 11 / 95$ & $\mathrm{TE}^{\mathrm{r}} \mathrm{SXT}^{\mathrm{r}}$ & c & s1 & p1 & h1 & iii \\
\hline S39 & $5 / 11 / 95$ & $\mathrm{TE}^{\mathrm{r}} \mathrm{SXT} \mathrm{T}^{\mathrm{r}}$ & $\mathrm{c}$ & s1 & p1 & h1 & iii \\
\hline $\mathrm{S} 40-\mathrm{S} 45$ & $27 / 11 / 95$ & $\mathrm{TE}^{\mathrm{r}} \mathrm{SXT} \mathrm{T}^{\mathrm{r}}$ & $\mathrm{c}$ & s1 & p1 & h1 & iii \\
\hline \multicolumn{8}{|c|}{ Outbreak 3 (Hsinchu County ${ }^{\dagger}$ ) } \\
\hline S46 & $13 / 10 / 97$ & $\mathrm{TE}^{\mathrm{r}} \mathrm{SXT} \mathrm{T}^{\mathrm{r}}$ & $\mathrm{d}$ & s1 & p1 & h1 & iv \\
\hline S47-S58 & $25 / 10 / 97$ & $\mathrm{TE}^{\mathrm{r}} \mathrm{SXT} \mathrm{T}^{\mathrm{r}}$ & $\mathrm{d}$ & s1 & p1 & h1 & iv \\
\hline \multicolumn{8}{|l|}{ Sporadic clinical isolates ${ }^{\S}$} \\
\hline S59 & $14 / 11 / 87$ & $\mathrm{TE}^{\mathrm{r}} \mathrm{NA}^{\mathrm{r}} \mathrm{C}^{\mathrm{r}} \mathrm{PIP}^{\mathrm{r}} \mathrm{SXT}^{\mathrm{r}} \mathrm{AM}^{\mathrm{r}}$ & e & s1 & p1 & h1 & $\mathrm{v}$ \\
\hline S60 & $16 / 11 / 87$ & TE $^{r}$ NA $^{r} C^{r}$ PIP $^{r}$ SXT $^{r}{ }^{\mathrm{A}}{ }^{\mathrm{r}}$ & e & s1 & p1 & h1 & $\mathrm{v}$ \\
\hline S61 & $19 / 6 / 86$ & $\mathrm{TE}^{\mathrm{r}} \mathrm{NA}^{\mathrm{r}} \mathrm{C}^{\mathrm{r}}$ & $\mathrm{f}$ & s1 & p1 & h1 & vi \\
\hline S62 & $11 / 8 / / 86$ & $\mathrm{TE}^{\mathrm{r}} \mathrm{NA}^{\mathrm{r}} \mathrm{C}^{\mathrm{r}} \mathrm{AM}^{\mathrm{r}}$ & $\mathrm{b}$ & s1 & p1 & h1 & vii \\
\hline S63 & $21 / 10 / 86$ & $\mathrm{TE}^{\mathrm{r}} \mathrm{NA}^{\mathrm{r}} \mathrm{C}^{\mathrm{r}} \mathrm{PIP}^{\mathrm{r}} \mathrm{AM}^{\mathrm{r}}$ & $\mathrm{g}$ & s1 & p1 & h1 & viii \\
\hline S64 & $4 / 11 / 86$ & $\mathrm{TE}^{\mathrm{r}} \mathrm{C}^{\mathrm{r}} \mathrm{PIP}$ & $\mathrm{g}$ & s1 & p1 & h1 & ix \\
\hline S65 & $2 / 8 / 85$ & $\mathrm{TE}^{\mathrm{r}} \mathrm{NA}^{\mathrm{r}} \mathrm{C}^{\mathrm{r}}$ & $\mathrm{h}$ & s1 & p1 & h1 & ix \\
\hline S66 & $5 / 9 / 85$ & $\mathrm{TE}^{\mathrm{r}}$ & $\mathrm{i}$ & $\mathrm{s} 2$ & $\mathrm{p} 2$ & $\mathrm{~h} 2$ & $\mathrm{x}$ \\
\hline
\end{tabular}

* Sensitive to all tested drugs.

${ }^{\dagger}$ Middle Taiwan.

Northern Taiwan.

${ }^{\S}$ Southern Taiwan.

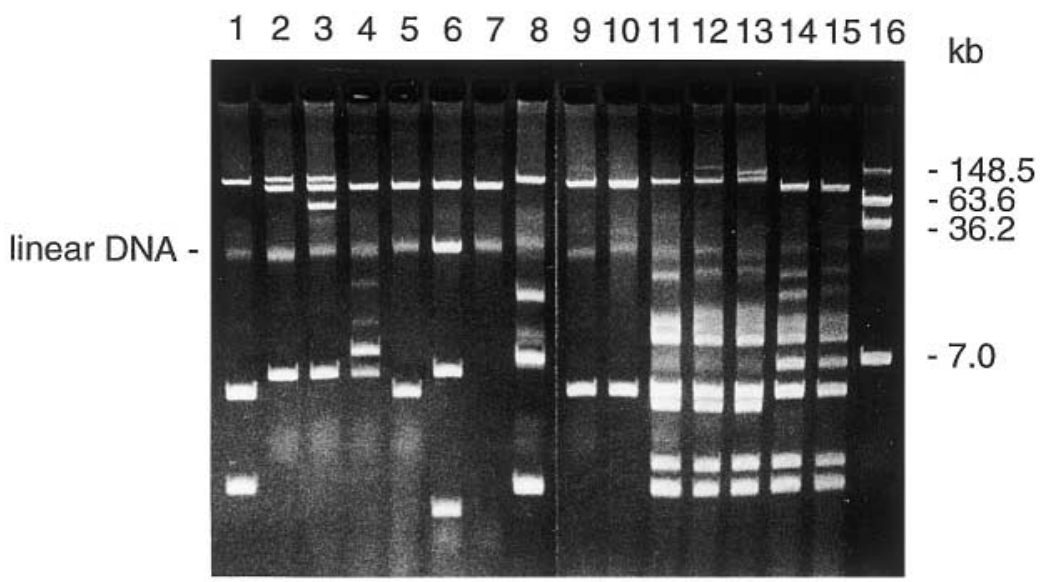

Fig. 1. Agarose gel electrophoresis profiles of plasmid DNA from S. sonnei isolates. Lane 1, type strain ATCC 9290; 2-6, sporadic clinical isolates S59-S63, respectively; 7, isolate S65; 8, isolate S66; 9 and 10, isolates $\mathrm{S} 11$ and $\mathrm{S} 15$ from outbreak 1; 11-13, isolates S26, S39 and S45 from outbreak 2; 14 and 15, isolates S46 and S47 from outbreak 3; 16, E. coli 39R861 as mol.wt marker (kb); linear DNA, fragmented plasmids and chromosomal DNA.

\section{Ribotyping}

To determine the optimal enzymes for achieving good resolution of DNA, preliminary tests were performed with restriction endonucleases HindII, PvuII, Sal I, EcoRI, BamHI, ScaI, HindIII and HinfI. Of the enzymes tested, HindII, PvuII and SalI provided the best distribution of bands and patterns were easily distinguishable. After restriction with these enzymes, all 58 outbreak strains, seven of eight sporadic isolates and type strain ATCC 9290 exhibited identical ribotypes as illustrated in Fig. 2a. Only isolate S66 possessed a distinct pattern regardless of the enzyme used. As shown in Fig. 2b (lanes 2, 4 and 6), the patterns of isolate S66 were different from those of isolate $\mathrm{S} 1$ (as representative of the other 65 isolates).

\section{PFGE}

PFGE resolution of DNA restricted with $X b a \mathrm{I}$ showed 10 restriction patterns consisting of 17-20 DNA fragments ranging in size from c. $20-500 \mathrm{~kb}$ in all 66 clinical isolates of $S$. sonnei and the type strain of the species (Table 1, Figs. 3 and 4). The strains from individual outbreaks were indistinguishable, whereas patterns from the three different outbreaks were distinct from each 
a

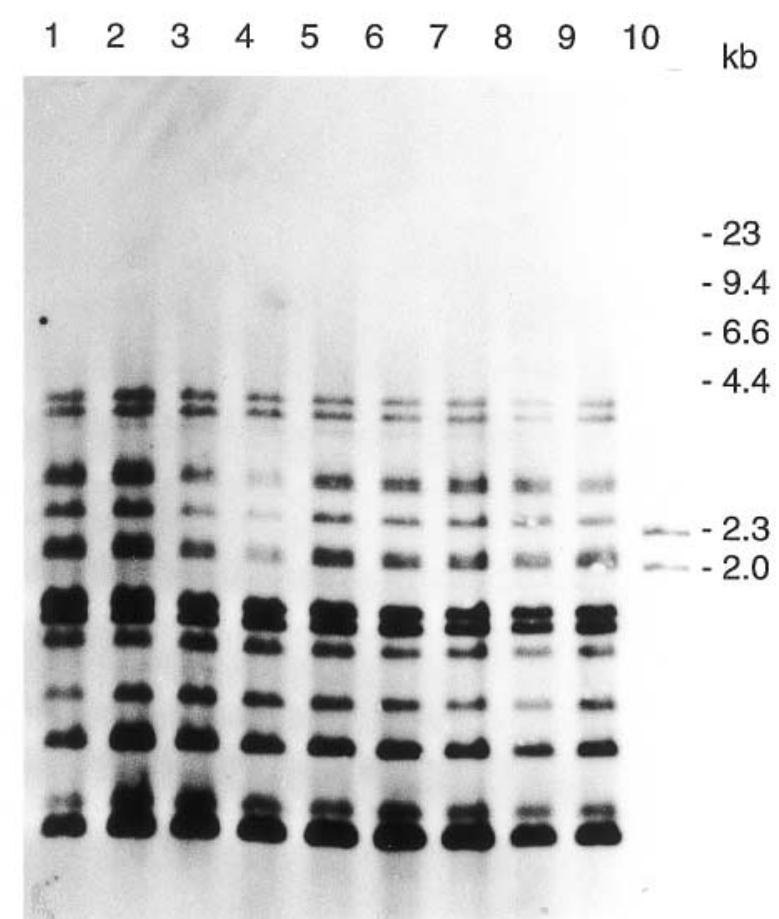

b

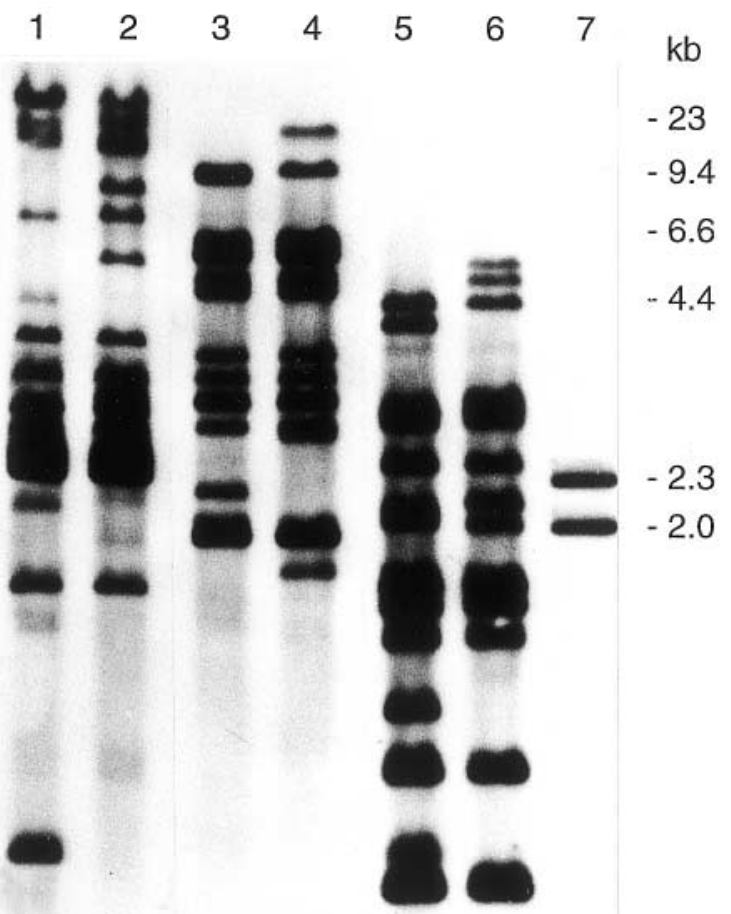

Fig. 2. (a) Ribosomal patterns of HindII restriction fragments of $S$. sonnei chromosomal DNA hybridised with diglabelled E. coli $16 \mathrm{~S}+23 \mathrm{~S}$ rRNA. Lane 1, type strain ATCC 9290; 2 and 3, outbreak 1 isolates (S1, S10); 4 and 5, outbreak 2 isolates (S26, S39); 6 and 7, outbreak 3 isolates (S46, S47); 8 and 9, sporadic isolates (S59, S65); 10, digoxigenin-labelled phage $\lambda$ DNA cut with HindIII as mol. wt marker (kb). (b) Ribosomal patterns of SalI (lanes 1 and 2), PvuII (3 and 4); HindII (5 and 6) restriction fragments of S. sonnei isolates S1 and S66 chromosomal DNA hybridised with dig-labelled E. coli $16 \mathrm{~S}+23 \mathrm{~S}$ rRNA. Lanes 1,3 and 5, isolate $\mathrm{S} 1 ; 2,4$ and 6, isolate S66; 7, digoxigenin-labelled phage $\lambda$ DNA cut with HindIII as mol.wt marker (kb).

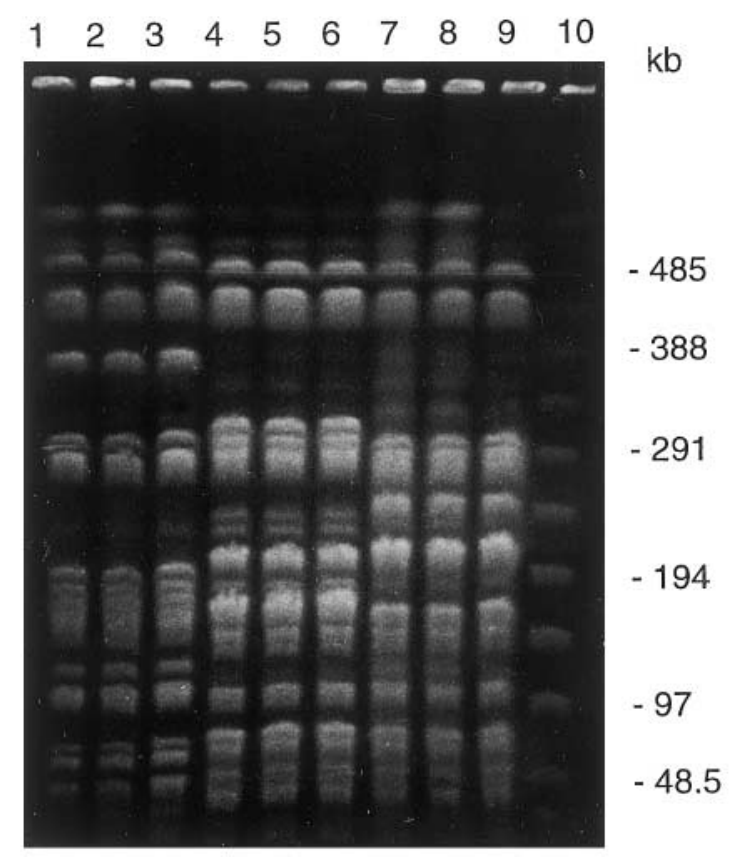

Fig. 3. $X b a \mathrm{I}$ restriction patterns of outbreak strains of $S$. sonnei isolates obtained by PFGE. Lanes 1-3, outbreak 1 strains (S1, S8, S13); 4-6, outbreak 2 strains (S26, S39, S40); 7-9, outbreak 3 strains (S46, S47, S58); 10, $\lambda$ ladder as mol. wt marker $(\mathrm{kb})$.

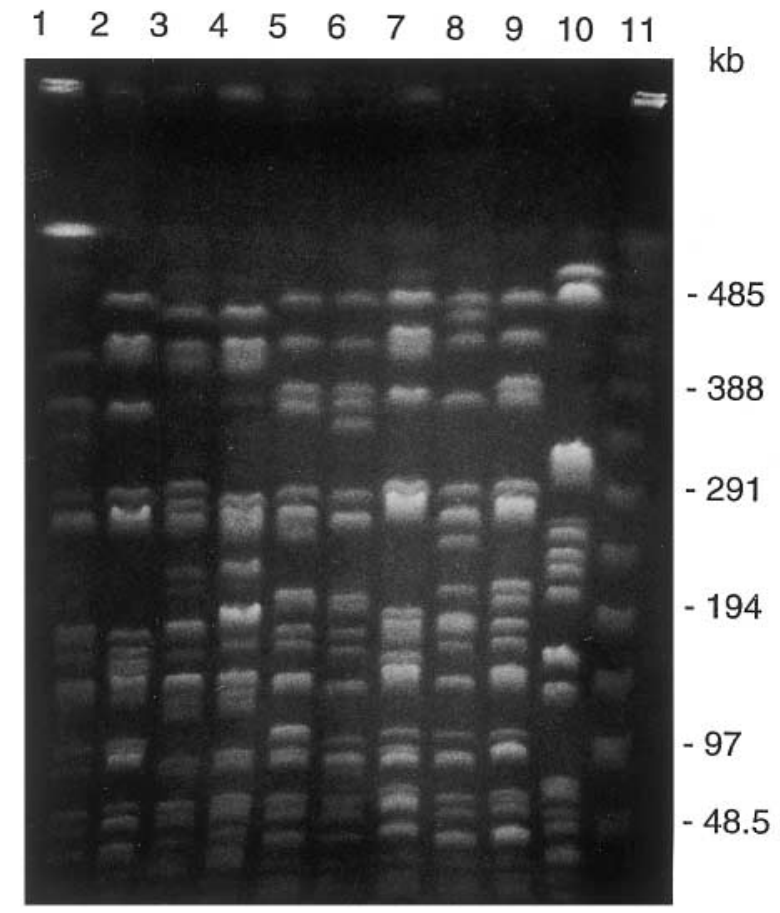

Fig. 4. XbaI restriction patterns of $S$. sonnei isolates obtained by the PFGE. Lane 1, type strain ATCC 9290; 2, isolate S1 (outbreak 1); 3, isolate S26 (outbreak 2); 4, isolate S46 (outbreak 3); 5-9, isolates S60-S64, respectively; 10, isolate $\mathrm{S} 66 ; \mathbf{1 1}, \lambda$ ladder as mol.wt marker $(\mathrm{kb})$. 
other. In contrast, eight sporadic isolates possessed six patterns (Table 1, v-x; Fig. 4, lanes 5-10). Among them, four isolates had individual patterns (vi, vii, viii, $\mathrm{x}$ ). The other four isolates shared two different patterns. Isolates S59 and S60 possessed pattern v, and isolates S64 and S65 had pattern ix (Table 1).

\section{Discussion}

In recent years, outbreaks of infection with $S$. sonnei have become an important public health problem in Taiwan. The concept of clonal expansion of microorganisms during common-source epidemics in contrast to multiple-source outbreaks is important in the epidemiology of infectious diseases. This study investigated the clonal relationship of $S$. sonnei among three well-documented outbreaks and compared them to those isolated from sporadic clinical infections by molecular typing methods.

Within a single outbreak, strains had identical antibiogram patterns. This result showed that the identification of a new or unusual pattern of antibiotic resistance among isolates cultured from multiple patients is often the first indication of epidemic spread. A previous study [2] and the report by Yagupsky et al. [21] showed that the genes of multiple drug resistance of $S$. sonnei were on the plasmids of $68-114 \mathrm{~kb}(45-$ $75 \mathrm{MDa}$ ). Although the outbreak strains in the present study shared three different plasmid profiles, they all possessed a plasmid of c. 68-114 kb (c. 45-75 MDa), which may carry the genes of multiple drug resistance.

Plasmid profile analysis is useful and extensively applied in the differentiation of isolates. Although this technique has limitations because it relies on the detection of extrachromosomal genetic elements which can readily be lost [22], an earlier study found that they had high specificities in different strains with different plasmid profiles in studies on Shigella spp. isolated from Southern Taiwan [2].

The present study showed the poor discriminatory power of ribotyping for $S$. sonnei isolates. This finding is similar to an earlier report on strains from Taiwan [14]. This limits the usefulness of ribotyping in epidemiological investigations of $S$. sonnei. Nastasi et al. [19] observed that 52 isolates from four Italian outbreaks at four different geographically dispersed sites during the years 1975-1991 exhibited the same ribotype, although three other outbreaks could be differentiated into three different ribotypes. However, ribotyping has been used successfully for $S$. sonnei in Spain [23] and other countries [24, 25].

PFGE has been shown to be a valuable typing method for epidemiological investigation of several bacterial pathogens [13, 26, 27] and clonality studies [28]. In interpreting chromosomal DNA restriction patterns produced by PFGE, Tenover et al. [29] have suggested that macro-restriction profiles of an isolate differing by more than six fragment positions can be considered to represent different strains. Thus, it is obvious that these three different well-documented outbreak strains should be considered as genetically distinct.

As plasmid profiling and PFGE are two different typing systems, and one cannot be replaced by another, they can complement each other in the subtyping of $S$. sonnei. Thus, strains that cannot be differentiated by either plasmid profiling or PFGE should be subtyped by a combination of these two means. In conclusion, PFGE and plasmid profiling were shown to be typing methods with a relatively high degree of discriminatory power that was superior to ribotyping. The diversity of PFGE patterns and plasmid profiles in this study suggests that these two techniques in combination are useful tools for epidemiological analysis of $S$. sonnei isolates.

This research was supported in part by a grant from the National Science Council, Republic of China (NSC 83-0412-B-037-059).

\section{References}

1. Pan TM. Recent trends in the epidemiology of shigellosis (in Chinese). Taipei, Taiwan, Department of Health, Execute Yuan, Republic of China. Epidemiol Bull 1996; 12: 212-219.

2. Lin S-R, Chang S-F. Drug resistance and plasmid profile of shigellae in Taiwan. Epidemiol Infect 1992; 108: 87-97.

3. DuPont HL, Levine MM, Hornick RB, Formal SB. Inoculum size, shigellosis and implications for expected mode of transmission. J Infect Dis 1989; 159: 1126-1128.

4. Arora DR, Midha NK, Ichhpujani RL, Chugh TD. Drug resistant shigellosis in north India. J Med Res 1982; 76: 74-79.

5. Kapperud G, Rørvik LM, Hasseltvedt V et al. Outbreak of Shigella sonnei infection traced to imported iceberg lettuce. $J$ Clin Microbiol 1995; 33: 609-614.

6. Morris GK, Wells JG. Colicin typing of Shigella sonnei. Appl Microbiol 1974; 27: 312-316.

7. Pruneda RC, Farmer JJ. Bacteriophage typing of Shigella sonnei. J Clin Microbiol 1977; 5: 66-74.

8. Aber RC, Mackel DC. Epidemiologic typing of nosocomial microorganisms. Am J Med 1981; 70: 899-905.

9. Tacket CO, Shahid N, Huq ML, Alim ARMA, Cohen ML. Usefulness of plasmid profiles for differentiation of Shigella isolates in Bangladesh. J Clin Microbiol 1984; 20: 300-301.

10. Litwin CM, Storm AL, Chipowsky S, Ryan KJ. Molecular epidemiology of Shigella infections: plasmid profiles, serotype correlation, and restriction endonuclease analysis. $J$ Clin Microbiol 1991; 29: 104-108.

11. Mendoza MC, Martín MC, González-Hevia MA. Usefulness of ribotyping in a molecular epidemiology study of shigellosis. Epidemiol Infect 1996; 116: 127-135.

12. Tee W, Lambert J, Smallwood R, Schembri M, Ross BC, Dwyer B. Ribotyping of Helicobacter pylori from clinical specimens. J Clin Microbiol 1992; 30: 1562-1567.

13. Brian MJ, Van R, Townsend I, Murray BE, Cleary TG, Pickering LK. Evaluation of the molecular epidemiology of an outbreak of multiply resistant Shigella sonnei in a Day-Care Center by using pulsed-field gel electrophoresis and plasmid DNA analysis. J Clin Microbiol 1993; 31: 2152-2156.

14. Liu PY-F, Lau Y-J, Hu B-S et al. Analysis of clonal relationships among isolates of Shigella sonnei by different molecular typing methods. J Clin Microbiol 1995; 33: 17791783.

15. Bauer AW, Kirby WM, Sherris JC, Turck N. Antibiotic susceptibility testing by a standardized single disk method. Am J Clin Pathol 1966; 45: 493-496. 
16. National Committee for Clinical Laboratory Standards. Performance standards for antimicrobial disk susceptibility tests, 15th edn. Approved standard: M2-A5. Villanova, PA, NCCLS. 1993.

17. Kado CI, Liu S-T. Rapid procedure for detection and isolation of large and small plasmids. J Bacteriol 1981; 145: 1365-1373.

18. Rochelle PA, Fry JC, Day MJ, Bale MJ. An accurate method for estimating sizes of small and large plasmids and DNA fragments by gel electrophoresis. J Gen Microbiol 1986; 132: 53-59.

19. Nastasi A, Pignato S, Mammina C, Giammanco G. rRNA gene restriction patterns and biotypes of Shigella sonnei. Epidemiol Infect 1993; 110: 23-30.

20. Maslow JN, Slutsky AM, Arbeit RD. Application of pulsedfield gel electrophoresis to molecular epidemiology. In: Persing DH, Smith TF, Tenover FC, White TJ (eds) Diagnostic molecular microbiology: principles and applications. Washington, DC, American Society for Microbiology Press. 1993: 563-572.

21. Yagupsky P, Loeffelholz M, Bell K, Menegus MA. Use of multiple markers for investigation of an epidemic of Shigella sonnei infections in Monroe County, New York. $J$ Clin Microbiol 1991; 29: 2850-2855.

22. Prado D, Murray BE, Cleary TG, Pickering LK. Limitation of using the plasmid pattern as an epidemiological tool for clinical isolates of Shigella sonnei. J Infect Dis 1987; 155: $314-316$.
23. Pace NR, Olsen GJ, Woese CR. Ribosomal RNA phylogeny and the primary lines of evolutionary descent. Cell 1986; 45: $325-326$.

24. Hinojosa-Ahumada M, Swaminathan B, Hunter SB et al. Restriction fragment length polymorphisms in rRNA operons for subtyping Shigella sonnei. J Clin Microbiol 1991; 29: 2380-2384.

25. Korpela J, Kärpänoja P, Taipalinen R, Siitonen A. Subtyping of Shigella sonnei for tracing nosocomial transmission. J Hosp Infect 1995; 30: 261-266.

26. Soldati L, Piffaretti JC. Molecular typing of Shigella sonnei using pulsed field gel electrophoresis and genome hybridization with insertion sequences. Res Microbiol 1991; 142: 489-498.

27. Thong K-L, Cheong Y-M, Puthucheary S, Koh C-L, Pang T. Epidemiologic analysis of sporadic Salmonella typhi isolates and those from outbreaks by pulsed-field gel electrophoresis. $J$ Clin Microbiol 1994; 32: 1135-1141.

28. Olsen JE, Skov MN, Threlfall EJ, Brown DJ. Clonal lines of Salmonella enterica serotype enteritidis documented by IS200-, ribo-, pulsed-field gel electrophoresis and RFLP typing. $J$ Med Microbiol 1994; 40: 15-22.

29. Tenover FC, Arbeit RD, Goering RV et al. Interpreting chromosomal DNA restriction patterns produced by pulsedfield gel electrophoresis: criteria for bacterial strain typing. J Clin Microbiol 1995; 33: 2233-2239. 